\title{
EXPERIÊNCIAS DE EDUCAÇÃO BILÍNGUE PARA SURDOS: ENTRELAÇAMENTOS ENTRE BRASIL E PORTUGAL*
}

\author{
Cássia Geciauskas Sofiato \\ Paulo Vaz de Carvalho \\ Orquídea Coelho
}

\section{Introdução}

Uma incursão na história da educação de surdos permite identificar a presença e a importância das línguas de sinais ou gestuais em diferentes períodos e espaços geográficos. Quando a educação de surdos passou a ser considerada como possível e realizada de forma intencional, a partir do século XVI, muitos dos pioneiros dessa empreitada levaram em consideração o alfabeto manual desenvolvido por Melchior Yebra, e depois por Pedro Ponce de León, que ganhou notoriedade, como forma de apoiar o trabalho de oralização, para soletrar palavras. A obra Reducción de las letras y arte para enseñar a hablar a los mudos, de Juan Pablo Bonet (1620), divulgou tal alfabeto e "atraiu a atenção de vários intelectuais europeus, inspirando alguns deles a dedicarem-se ao ensino de surdos" (CARVALHO, 2012, n.p).

John Bulwer, um médico inglês do século XVII, assinalou a existência de uma forma de comunicação dos surdos, mas à época, não reconhecida como língua. Com o esse status, percebe-se a presença do alfabeto manual e de uma língua de sinais ou gestual para fins pedagógicos nos séculos subsequentes, apesar da forte influência da abordagem oralista na educação de surdos.

Na França do século XVIII, pode-se observar a relevância que a língua de sinais ou gestual constituiu a partir do trabalho realizado pelo abade Charles Michel de L'Épée. De acordo com Carvalho (2012), este fundou o Instituto Nacional de Surdos-Mudos de Paris e tinha como base um método que reconhecia a língua de sinais francesa.

*DOI - 10.29388/978-65-86678-60-4-0-f.69-104 
A este método, L’Épée chamaria de gestos metódicos cuja descrição é apresentada nas suas duas principais obras: Institution des SourdsMuets par la voie des signes methodiques (1776) e La veritable maniére d'instruire les sourds et muets confinée par une longue experience (1784) (CARVALHO, 2012, p.1).

O século XIX foi palco de fortes controvérsias entre as duas filosofias presentes no momento na educação de surdos: a gestualista, iniciada pelo abade Charles Michel de L'Épée e continuada por outros expoentes, tais como Jacob Rodrigues Pereira na França e, a oralista, defendida por Samuel Heinicke, na Alemanha. Entretanto, todas as tentativas de representar e de valorizar a língua de sinais ou gestual foram aniquiladas pelo II Congresso Internacional de Educação de Surdos-Mudos, realizado em Milão no ano de 1880. De acordo com Witchs, Lopes e Coelho $(2019$, n.p):

A discussão gestualismo versus oralidade ocorre desde os primórdios da educação de surdos. Se tomarmos como exemplo países que têm sistemas de saúde e de educação mais avançados, como Suécia, Dinamarca, Noruega, Holanda e até mesmo Estados Unidos da América, as discussões sobre a surdez e o baixo alcance educacional dos surdos também são polêmicas (WITCHS; LOPES; COELHO, 2019 apud DIZEU; CAPORALI, 2005, p. 585-586).

No Congresso de Milão ficou acordado que a abordagem oralista deveria ser primordial para a educação e instrução de surdos. Depois dessa decisão ao nível mundial, tal abordagem predominou do fim do século XIX até meados do século XX, na Europa e na América. Entretanto, a crença no potencial da língua de sinais ou gestual nunca deixou de existir por parte de alguns pesquisadores, educadores e surdos. Prova disto é que a partir de 1960, por meio dos trabalhos de Willian Stokoe, a língua de sinais ou gestual ganhou o status de língua. Além de desenvolver padrões teóricos e metodológicos, ele a reconheceu como entidade linguística singular, tanto em seus aspectos de estruturação interna quanto em sua gramática (SACKS, 1990).

Após os estudos iniciados por Willian Stokoe, surgiram outros trabalhos, que lançaram um novo olhar em relação às línguas de sinais ou gestuais utilizadas por surdos ao redor do mundo. Apesar de os livros de Willian Stokoe terem sido criticados na época de sua publicação, não se pode negar que, em poucos anos, ocorreu uma revolução em duplo sentido: uma 
revolução cultural e política, e, além disso, científica, que dispensou atenção à língua de sinais ou gestuais e a seus substratos cognitivos e neurais. Nessa esteira, foram desenvolvidos estudos neurofuncionais (DONATO E DINIZ, 2017?), e estudos relativos à organização cerebral das línguas de sinais ou gestuais (Edward Klima e Úrsula Bellugi) que tiveram um grande impacto e contribuíram para a compreensão das noções de aquisição das línguas de sinais ou gestuais e para a educação de surdos.

Esse novo status da língua de sinais ou gestual ganhou mais força ao nível mundial a partir da década de 1980, com a abordagem do bilinguismo ${ }^{1}$. No Brasil, o bilinguismo passou a ser mais estudado, difundido e implementado a partir da década de 1990, por meio de autores filiados aos estudos culturais (SKLIAR, 1998, PERLIN, 1998).

A abordagem do bilinguismo na educação de surdos acena para a aquisição de, ao menos, duas línguas: a língua de sinais ou gestual como primeira língua (L1) e a língua oficial do país, como segunda língua, na modalidade escrita (L2). Porém, Skliar (1998) refere que não se trata apenas disso:

[...] o termo bilinguismo diz tudo mas, ao mesmo tempo, não diz nada acerca da educação para surdos. Diz tudo porque propõe e tende à construção de um ponto de partida a que não se pode renunciar: afirma a existência de duas línguas na vida dos surdos; mas não diz nada porque, por trás dessas línguas, há culturas, instrumentos cognitivos, modalidades de organização comunitária, formas de ver o mundo e conteúdos culturais que geralmente são omitidos ou não são reconhecidos como tais pelos ouvintes (p. 55).

\footnotetext{
${ }^{1} \mathrm{Na}$ abordagem do bilinguismo, o surdo é considerado um sujeito que possui uma língua que lhe é natural, que é a língua de sinais ou gestual (L1). Skliar (1998, p. 49) "os trabalhos da linguística pós-estruturalista avalizaram o status linguístico das línguas de sinais como línguas naturais e como sistemas diferenciados das línguas orais: o uso do espaço com valor sintático e topográfico e a simultaneidade dos aspectos gramaticais são algumas das restrições impostas pelo tipo de modalidade viso-espacial e determinam sua diferença estrutural em relação às línguas auditivoorais".
} 
Além do ensino das línguas, a educação bilíngue para surdos também pode se caracterizar como "uma oposição aos discursos e às práticas hegemônicas" (clínicas) e "como um reconhecimento político da surdez como diferença" (SKLIAR, 1999, p. 7). Nesse sentido, o bilíngue da educação de surdos tem uma dimensão mais alargada:

Discutir a educação bilíngue numa dimensão política assume um duplo valor: o político como construção histórica, cultural e social, e o político entendido como relações de poder e conhecimento que atravessam e delimitam a proposta e o processo educacional (SKLIAR, 1999, p. 7).

Ainda de acordo com o autor, a educação bilíngue para surdos, deveria propor a identidade dos surdos como um elemento norteador de práticas pedagógicas significativas, num contexto bilíngue e bicultural para além das fronteiras da escola e promover a plena participação dos surdos como cidadãos (SKLIAR, 1998). Tal discurso, apesar de ter sido proposto na década de 1990, ainda se mantém atual, diante de diferentes contextos mundiais e as peculiaridades da educação de surdos em cada país, de acordo com suas políticas públicas e educacionais. Podemos considerar que muito se avançou, mas desafios ainda se fazem presentes no que se refere ao bilíngue e bicultural na educação de surdos e seus encadeamentos, tendo em vista a inserção dos surdos em diversos espaços da vida social, possibilitados ou não pelo processo educacional.

Destarte, este estudo objetiva refletir, com base em alguns marcos legais relacionados com a educação de surdos no Brasil e em Portugal, implicações para a educação bilíngue e experiências escolares. Os países em questão assumem o bilinguismo como abordagem educacional e reconhecem a importância dos espaços bilíngues para o desenvolvimento pleno dos sujeitos surdos, além de contarem com um aporte legal específico para tal público. Outra singularidade que se apresenta quando tratamos da educação de surdos no Brasil e em Portugal é que nos referidos países tal empreitada teve início no século XIX, conferindo a ambos uma característica secular, marcada por uma trajetória consolidada em nível mundial.

A abordagem que caracteriza o presente estudo é qualitativa e a pesquisa bibliográfica e documental norteou a construção de um referencial circunstanciado para cada nação aqui proposta. Ancorados em Gil (2002), fez parte do corpus deste estudo, essencial: 
i) No Brasil: o Decreto Lei n, 5626 de 2005, que Regulamenta a Lei no 10.436, de 24 de abril de 2002, que dispõe sobre a Língua Brasileira de Sinais Libras, e o art. 18 da Lei no 10.098, de 19 de dezembro de 2000;

ii) Em Portugal: A Lei Constitucional de 1997, o Despacho Conjunto 105 de 97, o Despacho 7520 de 98, o Decreto-Lei 3/2008 e o Decreto-Lei 54 de 2018.

Para conferir a abordagem um caráter mais didático, optou-se pelo delineamento de cada contexto e posteriormente a explicitação dos entrelaçamentos possíveis, tendo em vista a perspectiva de Detienne (2004) sobre a construção de conjuntos comparáveis.

\section{Educação bilíngue de surdos no Brasil}

A educação bilíngue de surdos no Brasil, de acordo com os preceitos do bilinguismo, vem se constituindo na educação formal desde a década de 1990 e possui especificidades que envolvem a organização do espaço escolar (deaf space), o planejamento do currículo bilíngue, ao menos, em duas línguas; uma didática diferenciada; processos de avaliação compatíveis com o público em questão; a formação de profissionais para atuarem em tal contexto; o uso de recursos didáticos apropriados; entre outros aspectos.

O trabalho com a abordagem do bilinguismo e outros fatores, tais como a mobilização do movimento social surdo no Brasil contribuíram para que a língua brasileira de sinais (Libras) fosse reconhecida "como meio legal de comunicação e expressão" "oriundos de comunidades de pessoas surdas do Brasil", por meio da Lei no 10.436 de 2002 (BRASIL, 2002). No ano de 2005, houve a regulamentação da lei mencionada anteriormente por meio do Decreto-Lei no 5626 que, em seus nove capítulos, discorre sobre os direitos das pessoas surdas à educação, saúde, entre outros aspectos. Tal decreto promove a discussão e visibilidade da Libras uma vez que a referida língua é assunto dos nove capítulos que a compõem, cada um tratando de uma série de particularidades e suas devidas implicações.

O capítulo VI do Decreto-Lei no 5626 trata da garantia do direito à educação das pessoas surdas ou com deficiência auditiva. Neste capítulo, fazse menção às escolas de educação bilíngue para surdos e demais serviços educacionais que devem ser oferecidos para este público-alvo: 
Art. 22. As instituições federais de ensino responsáveis pela educação básica devem garantir a inclusão de alunos surdos ou com deficiência auditiva, por meio da organização de: I - escolas e classes de educação bilíngue, abertas a alunos surdos e ouvintes, com professores bilíngues, na educação infantil e nos anos iniciais do ensino fundamental; II escolas bilíngues ou escolas comuns da rede regular de ensino, abertas a alunos surdos e ouvintes, para os anos finais do ensino fundamental, ensino médio ou educação profissional, com docentes das diferentes áreas do conhecimento, cientes da singularidade linguística dos alunos surdos, bem como com a presença de tradutores e intérpretes de Libras - Língua Portuguesa.§ 10 São denominadas escolas ou classes de educação bilíngue aquelas em que a Libras e a modalidade escrita da Língua Portuguesa sejam línguas de instrução utilizadas no desenvolvimento de todo o processo educativo (BRASIL, 2005).

Os pressupostos expressos no Artigo 22, promoveram a organização de espaços escolares brasileiros de forma a considerar e validar o oferecimento da educação bilíngue para os alunos surdos. Entretanto, tal organização assume características específicas a partir do cruzamento do Decreto-Lei n. 5626 de 2005 com outras leis brasileiras ou documentos, tais como a Política Nacional de Educação Especial na Perspectiva da Educação Inclusiva de 2008. Lodi (2013) discorre sobre o teor de tais documentos:

Enquanto a Política de Educação Especial defende a inclusão dos alunos surdos no sistema regular de ensino, as comunidades surdas e pesquisadores da área, considerando a diferença linguística desse grupo social e o disposto no Decreto no 5.626/05, advogam que a educação de surdos constitui-se como um campo específico do conhecimento, distanciando-se da educação especial. Observou-se que o Decreto compreende educação bilíngue para surdos como uma questão social que envolve a língua brasileira de sinais (Libras) e a língua portuguesa, em uma relação intrínseca com os aspectos culturais determinantes e determinados por cada língua; a Política, por sua vez, reduz educação bilíngue à presença de duas línguas no interior da escola sem propiciar que cada uma assuma seu lugar de pertinência para os grupos que as utilizam, mantendo a hegemonia do português nos processos educacionais (p. 1). 
Com base no excerto apresentado, podemos perceber que a interpretação dos desdobramentos de uma educação bilíngue em termos de educação de surdos varia e determina diferentes encaminhamentos e ações nos espaços escolares.

Apoiados nas considerações apresentadas anteriormente, daremos destaque aos modelos de escolas presentes na educação de surdos no Brasil, que para fins deste estudo assumem três formatos, mas que não são implementados da mesma forma em todo o território nacional em função de particularidades de cada região, apesar de ser um direito da pessoa surda. Não obstante as diferenças de formato, todas assumem como pressuposto a educação bilíngue.

\section{A escola comum inclusiva}

A Lei Brasileira de Inclusão, Lei n ․ 13146 de 2015, no artigo 27 afirma que "a educação constitui direito da pessoa com deficiência, assegurados sistema educacional inclusivo em todos os níveis e aprendizado ao longo de toda a vida" (BRASIL, 2015). Neste sentido, a escola comum figura como uma possibilidade para alunos surdos. Em tal escola, considerando a base nacional comum e a parte diversificada proposta pela Lei de Diretrizes e Bases da Educação Nacional, no. 9394 de 1996, está previsto o oferecimento de disciplinas relacionadas com o ensino da "língua portuguesa, matemática, o conhecimento do mundo físico e natural e da realidade social e política, especialmente do Brasil" (BRASIL, 1996). Soma-se ao que já foi explicitado o ensino da língua inglesa (a partir do sexto ano do ensino fundamental), a disciplina de Artes e de Educação Física.

Nesse sentido, a língua de instrução na sala de aula da escola comum é a língua portuguesa, que será a base para o trabalho com todas as áreas do conhecimento e que também será trabalhada por meio de disciplina específica, ao longo de toda a educação básica. Neste espaço, a rigor, o ensino e aprendizado de Libras ocorrerão no atendimento educacional especializado para os alunos surdos (AEE) no contraturno. O documento Atendimento Educacional Especializado - Pessoa com surdez, publicado pelo Ministério da Educação (MEC) em 2007, traz ponderações acerca da educação inclusiva e o trabalho com alunos surdos: 
Ao optar-se em oferecer uma educação bilíngue, a escola está assumindo uma política linguística em que duas línguas passarão a coexistir no espaço escolar. Além disso, também será definido qual será a primeira língua e qual será a segunda língua, bem como as funções em que cada língua irá representar no ambiente escolar. Pedagogicamente, a escola vai pensar em como estas línguas estarão acessíveis às crianças, além de desenvolver as demais atividades escolares. As línguas podem estar permeando as atividades escolares ou serem objetos de estudo em horários específicos dependendo da proposta da escola. Isso vai depender de como, onde e de que forma as crianças utilizam as línguas na escola (BRASIL, 2007 APUD MEC/SEESP, 2006).

O referido documento prevê, especificamente, o trabalho com a Libras no AEE e com a língua portuguesa em três momentos didático-pedagógicos:

Momento do Atendimento Educacional Especializado em Libras na escola comum, em que todos os conhecimentos dos diferentes conteúdos curriculares são explicados nessa língua por um professor, sendo o mesmo preferencialmente surdo. Esse trabalho é realizado todos os dias e destina-se aos alunos com surdez. Momento do Atendimento Educacional Especializado para o ensino de Libras na escola comum, no qual os alunos com surdez terão aulas de Libras, favorecendo o conhecimento e a aquisição, principalmente de termos científicos. Este trabalho é realizado pelo professor e/ou instrutor de Libras (preferencialmente surdo), de acordo com o estágio de desenvolvimento da Língua de Sinais em que o aluno se encontra. $O$ atendimento deve ser planejado a partir do diagnóstico do conhecimento que o aluno tem a respeito da Língua de Sinais. Momento do Atendimento Educacional Especializado para o ensino da Língua Portuguesa, no qual são trabalhadas as especificidades dessa língua para pessoas com surdez. Este trabalho é realizado todos os dias para os alunos com surdez, à parte das aulas da turma comum, por uma professora de Língua Portuguesa, graduada nesta área, preferencialmente. $O$ atendimento deve ser planejado a partir do diagnóstico do conhecimento que o aluno tem a respeito da Língua Portuguesa (BRASIL, 2007, p.25).

Este documento ressalta que, no momento didático pedagógico relativo ao ensino de Libras, o profissional responsável pelo trabalho (professor e/ou instrutor de Libras - preferencialmente surdo) desenvolverá 
seu trabalho a partir do estágio de desenvolvimento da língua de sinais em que o aluno se encontra. Em tal documento está expresso que o planejamento do AEE deve ser feito pelo professor respeitando as especificidades da língua brasileira de sinais. Além disso, ênfase é dada ao estudo de termos científicos a serem abordados nos conteúdos escolares. No que tange à língua portuguesa, o documento prescreve que o trabalho deve ser realizado por uma professora graduada em tal língua e com base no nível de desenvolvimento linguístico do aluno.

Outro documento que discorre sobre o ensino de Libras e da língua portuguesa faz parte da série $A$ Educação Especial na Perspectiva da Inclusão Escolar e intitula-se Abordagem Bilíngue na Escolarização de Pessoas com Surdez (BRASIL, 2010). Nos textos introdutórios, apresentam-se as premissas para o trabalho com alunos surdos no contexto inclusivo e define-se que "a proposta de educação bilíngue pauta a organização da prática pedagógica na escola comum, na sala de aula comum e no AEE" (BRASIL, 2010, p. 9).

As pessoas com surdez não podem ser reduzidas ao chamado mundo surdo, com uma identidade e uma cultura surda. É no descentramento identitário que podemos conceber cada pessoa com surdez como um ser biopsicossocial, cognitivo, cultural, não somente na constituição de sua subjetividade, mas também na forma de aquisição e produção de conhecimentos, capazes de adquirirem e desenvolverem não somente os processos visuais-gestuais, mas também de leitura e escrita, e de fala se desejarem (BRASIL, 2010, p. 8).

Neste material, além do conteúdo que trata do AEE para alunos surdos e suas implicações, destaca-se que a língua de instrução do AEE é a Libras. Ele traz em um dos capítulos aspectos referentes à gramática da Libras e considerações sobre termos técnico-científicos das diferentes áreas do conhecimento em Libras. Em relação ao ensino da língua propriamente dito, o documento salienta que o professor responsável pelo trabalho deve fazer o planejamento com base na avaliação do conhecimento que o aluno tem a respeito da Libras e que o trabalho deve ser realizado de acordo com o estágio de desenvolvimento da língua dos alunos. Além disso, o professor precisa: 
Planejar o ensino dessa língua a partir dos diversos aspectos que envolvem sua aprendizagem, como: referências visuais, anotação em língua portuguesa, dactilologia (alfabeto manual), parâmetros primários e secundários, classificadores e sinais. Para atuar no ensino de Libras, o professor do AEE precisa ter conhecimento estrutura e fluência na Libras, desenvolver os conceitos em Libras de forma vivencial e elaborar recursos didáticos (BRASIL, 2010, p. 17).

Neste documento, percebe-se que há uma ênfase em relação aos aspectos fonológicos da língua, pois, além do delineamento de tal nível linguístico na seção que se dedica à gramática, no trecho dedicado à orientação para a avaliação da aprendizagem de Libras, o documento recomenda:

O professor do AEE avalia sistematicamente a aprendizagem dos alunos em Libras: conhecimento dos sinais, fluência e simetria. Em fluência e simetria, analisam: configuração de mão; ponto de articulação; movimento; orientação e expressão facial. Avaliam também o emprego de termos técnico-científicos, de acordo com o ano ou ciclo escolar em que o aluno se encontra (BRASIL, 2010, p. 18).

O trabalho desenvolvido pelo Atendimento Educacional Especializado, apesar de existir uma previsão legal para a sua viabilização, assume diferentes características em território nacional.

Os documentos descritos ainda têm sido utilizados como referência para muitos sistemas de ensino, levando-se em consideração as suas particularidades e modos de operacionalização. Como mencionado anteriormente, observa-se neste modelo a hegemonia da língua portuguesa, uma vez que é a língua de instrução utilizada pela escola comum (LODI, 2013) e o ensino e difusão da Libras fica a cargo do AEE em momentos didáticos planejados. Neste modelo de escola, a presença do tradutor e intérprete de língua brasileira de sinais é fundamental para que o aluno surdo possa ser inserido e participar de todas as atividades acadêmicas:

Art. 23. As instituições federais de ensino, de educação básica e superior, devem proporcionar aos alunos surdos os serviços de tradutor e intérprete de Libras - Língua Portuguesa em sala de aula e em outros espaços educacionais, bem como equipamentos e tecnologias que 
viabilizem o acesso à comunicação, à informação e à educação (BRASIL, 2005).

Entretanto, a presença e pertença deste profissional em espaços educacionais nos seus mais variados níveis ainda é um desafio na realidade brasileira, apesar da previsão legal e das matrículas dos alunos surdos.

\section{A escola bilíngue}

Outra possibilidade garantida por lei a alunos surdos é a escola bilíngue. Nestas escolas, as línguas de instrução são, a rigor, a língua brasileira de sinais (L1) e a língua portuguesa (L2) na modalidade escrita e ambas são utilizadas no processo educativo (BRASIL, 2005). Ademais, na escola bilíngue dimensiona-se que, minimamente, a cultura surda perpasse o currículo escolar e que os professores e demais profissionais que atuam neste espaço sejam bilíngues.

Dentro desta perspectiva, cada estado brasileiro tende a assumir um modelo bilíngue de acordo com as suas particularidades e possibilidades em termos financeiros, de gestão e condução didático-pedagógica. Isso ocorreu em algumas localidades após a publicação do Decreto-Lei n. 5626 de 2005, entretanto, pode-se dizer que não são todos os estados e municípios do país que oferecem tal possibilidade pelas mais variadas questões: por falta de recursos financeiros para arcar com este tipo de estrutura escolar, falta de profissionais para compor o quadro administrativo-pedagógico, número reduzido de alunos surdos, priorização da escola comum para o alunado surdo, entre outros aspectos.

Para uma melhor delimitação de uma escola bilíngue e organização, nossa análise tomará como referência as escolas bilíngues para surdos do município de São Paulo, lembrando que a autonomia para a organização de tais espaços também está implícita no Decreto- Lei №. 5626 de 2005.

Em 2011, o município de São Paulo criou as escolas bilíngues, por meio do Decreto $\mathrm{n}$-52.785, com a finalidade de reorganizar a proposta curricular na perspectiva da educação bilíngue, em Libras e em língua portuguesa; 
Art. 10 Ficam criadas as Escolas Municipais de Educação Bilíngue para Surdos - EMEBS na Rede Municipal de Ensino, vinculadas à Secretaria Municipal de Educação, destinadas a crianças, jovens e adultos com surdez, com surdez associada a outras deficiências, limitações, condições ou disfunções, e surdo-cegueira, cujos pais do aluno, se menor, ou o próprio aluno, se maior, optarem por esse serviço (SÃO PAULO, 2011, n.p.).

A portaria no 5.707, de 12 de dezembro de 2011, regulamentou o decreto 52.785 de 2011 que criou as escolas de educação bilíngue para surdos - EMEBS. Em tal portaria, a Libras é reconhecida como língua de instrução e que "anula a deficiência linguística, consequência da surdez, permitindo que as pessoas surdas se constituam como membros de uma comunidade linguística minoritária" (SÃO PAULO, 2011).

Dentro desta perspectiva, a Libras é ensinada por instrutores (preferencialmente surdos) ou professores bilíngues e:

§ 2o - A LIBRAS integrará o Quadro Curricular como componente curricular da parte diversificada e deverá possibilitar aos alunos surdos o acesso ao conhecimento, a ampliação no uso social da língua bem como a reflexão sobre a sua gramática, sobre o funcionamento da língua nos diferentes usos e o conhecimento da cultura surda. Grifo nosso (SÃO PAULO, 2011, n.p.).

Apesar de a Libras estar prevista como componente da parte diversificada do currículo e este fato ser um avanço no que se refere a organização de uma escola bilíngue, a sua carga horária ainda é inferior se compararmos a carga horária da disciplina de língua portuguesa. A portaria $\mathrm{n}$ 6571 de 2014, que Institui as Matrizes Curriculares para as Escolas Municipais de Ensino Fundamental (EMEFs), Escolas Municipais de Ensino Fundamental e Médio (EMEFMs), Escolas Municipais de Educação Bilíngue para Surdos (EMEBSs) e dá outras providências, destaca Libras na matriz curricular (exemplo do oferecimento diurno): 
Figura 1. Anexo IV da Portaria no 6571 de 2014

\begin{tabular}{|c|c|c|c|c|c|c|c|c|c|c|c|}
\hline \multicolumn{12}{|c|}{ MATRIZ CURRICULAR } \\
\hline \multicolumn{12}{|c|}{ LEIS FEDERAIS NNS 9.394/96 E 11.274/06 E RESOLUÇŌES CNE/CEB 04/09, 04/10 E 07/10 } \\
\hline \multirow{3}{*}{$\begin{array}{c}\text { BASE } \\
\mathrm{N}\end{array}$} & \multirow{3}{*}{$\begin{array}{c}\text { Áreas de } \\
\text { Conhecimento }\end{array}$} & \multirow{3}{*}{$\begin{array}{l}\text { Componentes } \\
\text { Curriculares }\end{array}$} & \multicolumn{9}{|c|}{ Horas-aula semanais } \\
\hline & & & \multicolumn{3}{|c|}{ Alfabetização } & \multicolumn{3}{|c|}{ Interdisciplina } & \multicolumn{3}{|c|}{ Autoral } \\
\hline & & & 12 & $2^{2}$ & 39 & $4 \%$ & 59 & 6? & 79 & 89 & 99 \\
\hline $\begin{array}{l}\text { A } \\
\text { C }\end{array}$ & \multirow[t]{3}{*}{ Linguagens } & $\begin{array}{c}\text { Lingua } \\
\text { Portuguesa }\end{array}$ & 6 & 6 & 6 & 6 & 6 & 6 & 6 & 6 & 6 \\
\hline 1 & & Arte & $1^{*}$ & $1^{*}$ & $1^{*}$ & $1^{*}$ & $1^{*}$ & 2 & 2 & 2 & 2 \\
\hline $\begin{array}{l}0 \\
N\end{array}$ & & Ed. Fisica & $2^{*}$ & $2^{*}$ & $2 *$ & $2^{*}$ & $2^{*}$ & 3 & 3 & 3 & 3 \\
\hline A & Matemática & Matemática & 5 & 5 & 5 & 5 & 5 & 5 & 5 & 5 & 5 \\
\hline \multirow{3}{*}{$\stackrel{\mathrm{L}}{\text { comum }}$} & Ciências da Natureza & Ciências & 3 & 3 & 3 & 3 & 3 & 3 & 3 & 3 & 3 \\
\hline & \multirow[t]{2}{*}{ Ciências Humanas } & Geografia & 3 & 3 & 3 & 3 & 3 & 3 & 3 & 3 & 3 \\
\hline & & História & 3 & 3 & 3 & 3 & 3 & 3 & 3 & 3 & 3 \\
\hline \multicolumn{3}{|c|}{ Total da Base Nacional Comum } & 23 & 23 & 23 & 23 & 23 & 25 & 25 & 25 & 25 \\
\hline $\begin{array}{c}\text { Parte } \\
\text { Diversificada }\end{array}$ & $\begin{array}{c}\begin{array}{c}\text { Língua Brasileira } \\
\text { de } \\
\text { Sinais }\end{array} \\
\end{array}$ & UIBRAS & 5 & 5 & 5 & 5 & 5 & 3 & 3 & 3 & 3 \\
\hline \multicolumn{3}{|c|}{ Total da Parte Diversificada } & 5 & 5 & 5 & 5 & 5 & 3 & 3 & 3 & 3 \\
\hline \multicolumn{3}{|c|}{ Total da Carga Horária } & 28 & 28 & 28 & 28 & 28 & 28 & 28 & 28 & 28 \\
\hline \multicolumn{3}{|c|}{ Ensino Religioso } & 1 & 1 & 1 & 1 & 1 & 1 & 1 & 1 & 1 \\
\hline
\end{tabular}

Fonte: São Paulo (2014)

\begin{tabular}{|c|c|c|c|c|c|c|c|c|c|}
\hline \multicolumn{10}{|c|}{ ENRIQUECIMENTO CURRICULAR - LEI FEDERAL N2 9.394 - Artigo 34} \\
\hline & \multicolumn{3}{|c|}{ Alfabetização } & \multicolumn{3}{|c|}{ Interdisciplinar } & \multicolumn{3}{|c|}{ Autoral } \\
\hline & $1^{2}$ & 29 & 32 & 42 & 59 & 6? & 72 & 82 & 99 \\
\hline Sala de Leitura & 1 & 1 & 1 & 1 & 1 & 1 & 1 & 1 & 1 \\
\hline Laboratório de Informática Educativa & 1 & 1 & 1 & 1 & 1 & 1 & 1 & 1 & 1 \\
\hline TOTAL & 2 & 2 & 2 & 2 & 2 & 2 & 2 & 2 & 2 \\
\hline
\end{tabular}

\begin{tabular}{|c|c|c|c|c|c|c|c|c|c|}
\hline \multicolumn{10}{|c|}{ DOCÊNCIA COMPARTILHADA - DECRETO N $54.452 / 13$} \\
\hline & \multicolumn{3}{|c|}{ Alfabetização } & \multicolumn{3}{|c|}{ Interdisciplinar } & \multicolumn{3}{|c|}{ Autoral } \\
\hline & $1^{2}$ & $2^{2}$ & 39 & $4^{e}$ & 5? & 6? & $7^{2}$ & $8 ?$ & $9^{9}$ \\
\hline Projetos & - & - & - & $1 \approx$ & $2 \pi$ & $3^{*}$ & - & - & - \\
\hline Lingua Brasileira de Sinais - UBRAS & 3 & 2 & 2 & 2 & 2 & $1 \cdots$ & - & - & - \\
\hline TOTAL & 3 & 2 & 2 & 3 & 4 & 4 & - & - & - \\
\hline \multicolumn{10}{|c|}{ - $N^{2}$ de aulas de orientaçào de projetos de acordo $\operatorname{com} 053^{9}$ do art. $7^{9}$ da Portaria $n^{2} 5.930 / 13$} \\
\hline \multicolumn{10}{|c|}{ "N? de aulas estabelecidas de acordo com inciso II do art. 89 da Portaria $n^{2} 5930 / 13$} \\
\hline
\end{tabular}

- 28 horas-aula $\times 40$ semanas $=1.120$ horas-aula

-1.120 horas-aula $X 45$ minutos $=50.400$ minutos

-50.400 minutos +6.000 minutos (recreio e atividades orientadas) $=56.400$ minutos

- 02 horas-aula (enriquecimento curricular) $\times 40$ semanas $=80$ horas-aula

-80 horas-aula $\times 45$ minutos $=3.600$ minutos

-3.600 minutos +56.400 minutos $=60.000$ minutos ou 1.000 horas

Fonte: São Paulo (2014)

De acordo com a Política Paulistana de Educação Especial, na Perspectiva da Educação Inclusiva, a "Educação Bilíngue deverá contemplar os Componentes Curriculares da Base Nacional Comum e as condições didático- 
pedagógicas para que a Libras e a língua portuguesa constituam línguas de instrução, comunicação e de circulação na escola" (SÃO PAULO, 2016, p. 12). As unidades educacionais oferecem os seguintes níveis de escolarização: Educação Infantil, Ensino Fundamental I e II, Educação de Jovens e Adultos (EJA).

O ensino de Libras e de língua portuguesa tem atenção especial no município em questão. No ano de 2008, 2012 e 2019 foram publicados documentos com o intuito de nortear o encaminhamento curricular e metodológico do ensino das referidas línguas: i) 2008-Orientações Curriculares e Proposição de Expectativas de Aprendizagem para a Educação Infantil e Ensino Fundamental: língua brasileira de sinais- Libras e Orientações curriculares e Proposição de Expectativas de Aprendizagem para a Educação Infantil e Ensino Fundamental: língua portuguesa para pessoa surda; ii) 2012Caderno de apoio a aprendizagem de LIBRAS - 1 ano ao 5 으o do ensino fundamental;

iii) 2019- Currículo da cidade: Educação Especial: Língua Brasileira de Sinais e Currículo da cidade: Educação especial: Língua Portuguesa para surdos.

As referidas obras têm por finalidade aprimorar e nortear o ensino e a aprendizagem da Libras e da língua portuguesa, de forma a acompanhar a tendência do município, no que tange às publicações relacionadas a educação básica.

De acordo com Santos (2018), a portaria no 5.707 de 2011 explicita o modelo bilíngue no município, enfatizando:

A organização da educação oferecida nos diferentes níveis de ensino, a posição da língua brasileira de sinais e da língua portuguesa no ensino dos surdos, a Libras aparecendo como língua de instrução e também como disciplina presente na Parte Diversificada do currículo, as propostas de ensino de Libras para a comunidade, os profissionais que atuam na escola bilíngue e suas respectivas formações, o módulo de crianças por turma, a caracterização das Unidades-Polo, entre outras disposições (SANTOS, 2018, p. 175).

Com base nos aspectos salientados pertencentes à proposta de educação bilíngue oferecida pela rede municipal de São Paulo, podemos inferir que são muitos os aspectos envolvidos para a implementação e funcionamento de um modelo desta natureza. Além da garantia das línguas de 
instrução específicas, a necessidade de conceber um deaf space, o apoio de recursos didáticos e a formação de profissionais bilíngues são fatores imprescindíveis para a consolidação deste tipo de escola.

Outro ponto que faz a diferença são as práticas pedagógicas que numa escola bilíngue levam em consideração a linguagem visual de forma imprescindível para o alunado surdo. O desenvolvimento do currículo por meio da linguagem visual pode potencializar o ensino e a aprendizagem de conteúdos das variadas áreas do conhecimento. Entretanto, o trabalho com este tipo de linguagem requer formação e planejamento por parte dos professores ou instrutores surdos.

A defesa e até mesmo a manutenção de escolas bilíngues ainda se faz necessária no Brasil em algumas regiões, tendo em vista o cenário político de cada localidade e sua adesão ou não a tal modelo, apesar da legitimidade legal.

\section{Escolas polo bilíngues}

Para definir a proposta deste tipo de escola recorreremos, mais uma vez, ao trabalho desenvolvido no município de São Paulo. Porém, é importante salientar que escolas com esta configuração também funcionam em alguns outros municípios nos diversos estados do Brasil e podem possuir características diferentes das que serão mencionadas a seguir.

As unidades polo bilíngues, de acordo com a Secretaria Municipal de Educação de São Paulo, são escolas regulares bilíngues com características inclusivas e atendem alunos surdos e ouvintes (SÃO PAULO, 2011). Tais escolas são regulares, mas possuem uma estrutura específica para o trabalho com os estudantes surdos. No município de São Paulo são duas as unidades polo bilíngue, que junto a escolas bilíngues fazem parte dos serviços pertencentes à Educação Especial.

Nas unidades polo bilíngue, objetiva-se que desde os anos iniciais do ensino fundamental sejam desenvolvidas a Libras e a língua portuguesa com os alunos surdos, acompanhando o fluxo da escola em termos curriculares. A Política Paulistana de Educação Especial, na Perspectiva da Educação Inclusiva de 2016 (p. 12), prevê para tais espaços educacionais os seguintes profissionais: "para as Unidades Polo de Educação Bilíngue e as escolas comuns, instrutor de Libras, preferencialmente surdo, intérprete de Libras/língua portuguesa e guia-intérprete de Libras/língua portuguesa". 
Segundo o referido documento, as unidades polo bilíngues possuem as Classes Bilíngues I e as Classes Bilíngues II. Com o intuito de organizar o trabalho bilíngue da rede municipal de São Paulo, o comunicado no 567 de 2012, da Secretaria Municipal de Educação, explicita o trabalho previsto para classes bilíngues I:

Bilingue I: classe de educação bilíngue que receberá a matrícula dos alunos surdos e oferecerá a LIBRAS como língua de instrução, na seguinte conformidade:

2.1.1 - Na Educação Infantil composta por alunos surdos do Infantil I e Infantil II;

2.1.2 - No Ensino Fundamental I composta por alunos surdos do 10 ao 50 ano e as classes organizadas por ano do ciclo, podendo, excepcionalmente, serem organizadas agrupando alunos dos diferentes anos do ciclo I (SÃO PAULO, 2012, n.p.)

Ademais, tal documento também prescreve o trabalho a ser desenvolvido na classe bilíngue II:

Bilíngue II: atenderá, prioritariamente, os alunos matriculados nas classes do Ensino Fundamental II, no componente Língua Portuguesa, ministrada no mesmo horário daquela ofertada para alunos ouvintes, com metodologia de ensino de segunda Língua e poderá oferecer também o atendimento educacional especializado e LIBRAS, para alunos, no contraturno escolar, bem como para a comunidade escolar (SÃO PAULO, 2012, n.p.)

Nas unidades polo bilíngue, assim como nas escolas bilíngues do município, estão previstas aulas de Libras para familiares dos alunos surdos, funcionários da escola e pessoas da comunidade. No caso das unidades polo bilíngue, estão previstas aulas de Libras como segunda língua para alunos ouvintes.

Assim como as escolas bilíngues, as unidades polo bilíngue demandam um grande investimento para funcionar da forma planejada e assertiva para o alunado surdo. Dessa forma, é um modelo bastante interessante, mas depende do trabalho colaborativo entre todos os membros da comunidade escolar para que consiga levar a cabo a sua missão educacional. 


\section{A educação bilíngue de surdos em Portugal}

Segundo Gregory (1996), a educação bilíngue é uma abordagem à educação de crianças surdas que usa a língua gestual da Comunidade Surda e a língua escrita/ oral da comunidade ouvinte circundante.

Em Portugal, as primeiras abordagens à educação bilíngue para crianças e jovens surdos surgiram nas décadas de 1970, 1980 e 1990 , numa primeira fase como reação aos métodos oralistas e numa segunda fase através da influência de parcerias com a Suécia e com os Estados Unidos da América (EUA), curiosamente os dois países que não ratificaram as resoluções do Congresso de Milão de 1880.

Se adotarmos a definição de Gregory (1996) para a educação bilíngue, não podemos deixar de revisitar a educação de surdos no século XIX onde este conceito poderá ter começado a ser construído embora com outras nomenclaturas. Terá sido o Abade Charles Michel de L'Épée o primeiro professor a reconhecer a existência de uma forma de comunicação gestual na Comunidade Surda francesa e usá-la na educação de crianças surdas.

[...] Todo o surdo-mudo enviado até nós já tem uma linguagem [...] Têm o hábito de usá-la e compreendem os outros que a usam. Com essa linguagem ele expressa as suas necessidades, desejos, dúvidas, dores, etc... Nós desejamos instruí-los e assim ensinar-lhes o francês. Qual é o método mais simples e mais curto? Não seria expressando-nos na sua língua? (L'ÉPÉE, 1776, 36).

Todavia, L'Épée nunca ensinou a Langue des Signes Française (LSF) mas utilizou-a como um método ou mesmo uma interlíngua para ensinar o francês escrito que intitulou de "Gestos/Sinais Metódicos". O seu sucessor à frente do Instituto de Surdos francês, o Abade Sicard terá ido mais longe ao formar os primeiros professores surdos da História. Devemos também destacar a obra de Roch-Ambroise Bébian, professor ouvinte do Instituto francês que estudou pela primeira vez uma língua gestual de forma aprofundada fazendo uma complexa descrição da LSF na sua obra Mimographie (1825) e as obras Manuel d'enseignement pratique des sourds-muets, Tome I e II (1827), os primeiros manuais desenvolvidos para a educação de surdos contemplando assim o uso das duas línguas na educação de surdos e por isso bilíngue. 
Em Portugal, no século XIX dois professores de surdos também contemplaram as duas línguas na educação de surdos e talvez tenham ido mais longe que os seus colegas franceses em relação a metodologia de ensino: Per Aron Borg e o Padre Pedro Maria de Aguilar.

Per Aron Borg, fundador do primeiro Instituto de Surdos-Mudos e Cegos da Suécia (1809), foi convidado pelo Rei Português D. João VI a vir fundar em Portugal o Real Instituto de Surdos-Mudos e Cegos em 1823. A metodologia de ensino de Surdos de Borg assentava no ensino da língua gestual, da dactilologia e da língua portuguesa escrita/ oral.

[...] descobriu-se o caminho pelo qual a alma do surdo-mudo pode penetrar pelos mesmos espaços abstractos, assim como, os seus semelhantes que gozam do dom de ouvir, achou-se para ele a chave de todos os conhecimentos humanos: Um Idioma e ele foi restituído àquela sociedade de entes racionaes e ilustrados [...] (ARON BORG, 1823).

Segundo Alves (2012) a planificação dos estudos dos surdos desenvolvido por Borg contemplava o método misto: a língua gestual/ sinais e a componente escrita e oral. Borg construiu uma tabela com um horário semanal onde expões os métodos e os ramos de ensino que consta num relatório que enviou à Infanta $\mathrm{D}$. Maria protetora do Instituto.

Tabela 1. Planificação de estudos dos surdos

\begin{tabular}{|c|l|}
\hline Dias da semana & \multicolumn{1}{|c|}{ Atividades } \\
\hline 2a feira & $\begin{array}{l}\text { No 10 tempo tinha lugar o ensino da nomenclatura dos novos objetos } \\
\text { com as respetivas explicações e os signaes/ gestos convencionados a } \\
\text { que correspondiam novas palavras. }\end{array}$ \\
\hline 3a feira & $\begin{array}{l}\text { No 10 tempo reviam-se as matérias do dia anterior com recurso a } \\
\text { exercícios de repetição. No 20 tempo tomava lugar a atividade escrita } \\
\text { em que os alunos recorrem a um livro ou caderno diário para } \\
\text { registarem as palavras. }\end{array}$ \\
\hline 4a feira & $\begin{array}{l}\text { Retoma-se o ensino de mais vocábulos e dos signaes/ gestos que lhes } \\
\text { correspondiam. }\end{array}$ \\
\hline 5a feira & $\begin{array}{l}\text { Consolidação dos conteúdos ministrados no dia anterior seguindo-se } \\
\text { exercícios de escrita. }\end{array}$ \\
\hline 6a feira & $\begin{array}{l}\text { Retomavam-se as aulas para ensinar novos vocábulos e respetivos } \\
\text { signaes/ gestos. }\end{array}$ \\
\hline Sábado & Consolidação dos conteúdos do dia anterior e registo escrito. \\
\hline
\end{tabular}

Fonte: Alves (2012) 
Todas as quartas-feiras e sábados, entre as 11 horas e as 12 horas, procedia-se à regularização dos novos signaes/gestos. Tratavam-se de gestos/sinais captados pelos discípulos e faziam referência ao novo vocabulário ministrado pelos mestres durante a semana. Das 24 horas semanais, 14 horas eram dedicadas ao ensino de gestos e três horas à articulação da fala, as horas restantes eram dedicadas ao ensino do português escrito dado pelo 3 o professor e repetidor Crispim da Cunha, já que Borg era estrangeiro e não dominava o português.

Fica bem patente que nesta metodologia desenhada por Per Aron Borg existia uma preocupação em ensinar os gestos da língua gestual e a língua escrita/oral do português dando os primeiros passos em direção à educação bilíngue, embora na época não existisse como nomenclatura, já existia como conceito.

Outro professor de surdos do século XIX cujo trabalho inovador devemos destacar, foi o Padre Pedro Maria de Aguilar, fundador do Colégio de Surdos-Mudos de Guimarães e mais tarde do Instituto Municipal de SurdosMudos do Porto. Também este privilegiava o ensino de duas línguas, a língua gestual e a língua portuguesa.

[...] O padre Aguilar começava o quanto antes com o ensino da linguagem escripta. Cada um dos alunos trazia uma ardósia de mão e as carteiras também tinham uma ardósia. [...] Primeiro ensinava o vocabulário e os respetivos signaes/gestos (FUSILLIER, 1892, 24).

O conhecimento que o Padre Aguilar tinha da estrutura da língua gestual era bastante claro e aprofundado o que revelava um estudo pioneiro na época e que permitia fazer a ponte com a língua escrita, premissa defendida para a educação bilíngue atual.

[...] Aqui o Padre Aguilar reivindicou uma inovação importante [...] os surdos-mudos pouco adeantados exprimem-se em geral com verbos no infinito, o que dá ao período uma forma curiosa, especial, que recebeu até o nome expressivo "Phrase do Surdo-Mudo"[...] Expressando-se por signaes, os surdos-mudos seguem rigorosamente a geração das ideas [...] (FUSILLIER, 1892, 25). 
D. António da Costa, escritor português do século XIX e amigo pessoal do Padre Aguilar na sua obra No Minho, no capítulo intitulado Assombro dos Surdos-Mudos, descreveu em pormenor o método do Padre Aguilar numa visita que fez ao Colégio de Guimarães.

[...] Principiou a sessão conversando por mímica, a professora com elles e elles uns com os outros [...] Nunca lhes foram impostos signaes do alfabeto pelos dedos, sistema ainda hoje na Europa usado. Não é o professor que decreta a linguagem mímica mas os próprios mudos é que estabelecem os signaes da conversação, conforme a própria razão Ih'os indica [...] (COSTA, 1874, 42).

Para o ensino da escrita da língua portuguesa, o Padre Aguilar desenvolveu um método muito próprio e inovador revelando um profundo conhecimento da forma de aprendizagem do português pelas crianças surdas.

[...] As orações não se lhes apresentam na grande pedra já construídas gramaticalmente. Pelo contrário, escrevem-se diversas colunas com nomes, verbos, conjunções, como materiais dispersos, para os mudos construírem as orações necessárias [...] Cada mudo vai designando rapidamente com o ponteiro as palavras de que usaríamos falando e travava-se entre eles não só o diálogo mas às vezes uma conversação [...] (COSTA, 1874, p. 45).

A noção do padre Aguilar era então inovadora, compreendendo que apenas pelo ensino funcional da língua escrita era possível ensinar a escrita do português aos alunos surdos, noção que ainda hoje não é clara para muitos profissionais que trabalham com alunos surdos.

Podemos constatar que os pressupostos basilares que hoje se defendem para a educação bilíngue de alunos surdos já estariam presentes nas metodologias desenvolvidas por estes dois professores do século XIX, pelo que não podemos negligenciar estas preciosas fontes, sob pena de concluirmos inadvertidamente que o ensino das duas línguas (língua gestual/ sinais e língua portuguesa escrita/ oral) a alunos surdos é uma criação da segunda metade do século XX.

A partir de 1905, com a implementação do método oral puro em Portugal pela mão de Nicolau Pavão de Sousa, as metodologias de ensino de surdos que acabamos de apresentar despareceram por completo das escolas 
de surdos, uma consequência das decisões tomadas no Congresso de Milão de 1880. A língua gestual desapareceu das salas de aula, embora continuasse a ser utilizada pelos alunos surdos nos lares, nos intervalos e nos refeitórios.

Os métodos oralistas (oral puro, materno-reflexivo e verbotonal) de ensino de surdos mantiveram-se em Portugal durante quase um século até as décadas de 1970, 1980 e 1990, quando começaram a ser postos em causa os seus resultados. Após quase um século de ensino oralista em Portugal surgiram as primeiras reações por parte dos professores, educadores, técnicos e da própria comunidade surda, colocando em causa os resultados e o sucesso deste método.

Segundo Gomes (2014), em 1973 criaram-se as Divisões de Ensino Especial, na Direção Geral de Ensino Básico e na Direção Geral do Ensino Secundário e, em 1976, foram criadas as Equipas de Ensino especial Integrado. É na transição da década de 1970 para a década de 1980 que começa a emergir em Portugal uma nova visão sobre a surdez e sobre a Língua Gestual, devido à cooperação com os países nórdicos nomeadamente com a Suécia Acordo Luso-Sueco (AFONSO, 2007).

Em 1981, o Secretariado Nacional de Reabilitação e Integração de Pessoas com Deficiência (SNRIPD) apoiou a formação de dois formadores surdos, José Bettencourt e João Alberto Ferreira na Universidade de Gallaudet nos EUA. Quando regressaram, estes dois formadores deram início à criação de vários cursos de formação de Língua Gestual Portuguesa (LGP) para professores e técnicos ouvintes.

Segundo Carvalho (2007), em 1983 efetuou-se a primeira tentativa de implementação de um modelo bilíngue de educação de surdos em Portugal na escola A-da-Beja liderado por Sérgio Niza (introdutor do movimento da Escola Moderna em Portugal) em conjunto com o formador de LGP José Bettencourt. Este projeto bilíngue abrangia três vertentes: o ensino da LGP, o ensino da leitura e escrita do português e o respeito pelo momento de aprendizagem de cada aluno surdo.

Gomes (2014) salienta que a Lei de Bases do Sistema Educativo (Lei n-46/86 de 14 de Outubro) veio dar suporte legal às experiências de integração das Direções de Educação Especial. No final dos anos 80, já existiam algumas turmas especiais de alunos surdos nos Núcleos de Apoio a Crianças Deficientes Auditivas (NACDAS). 
Paralelamente ao Ministério da Educação, também no Instituto Jacob Rodrigues Pereira (IJRP) da Casa Pia de Lisboa (Instituto que teve origem no Real Instituto de Surdos-Mudos e Cegos, fundado em 1823 por Per Aron Borg), os métodos oralistas começaram a ser postos em causa. Seria neste Instituto que foi implementada a educação bilíngue de alunos surdos de uma forma mais estruturada e assente em princípios científicos.

No início da década de 1990, o método verbotonal era ainda uma realidade no IJRP quando os professores Maria Augusta Amaral e Amândio Coutinho desenvolveram um estudo de cariz científico, apoiado pela Faculdade de Letras da Universidade de Lisboa, com um grupo de 100 alunos surdos com o objetivo de identificar as reais dificuldades que os jovens surdos apresentavam em relação aos aspetos comunicativos e linguísticos. Os resultados obtidos por este estudo revelaram as seguintes dificuldades por parte dos alunos surdos:

Domínio de um vocabulário estereotipado; não interiorização da estrutura da língua oral; incapacidade de apreensão de um texto escrito extremamente simples e curto; incapacidade de utilizar a escrita com correção ou de tratar de forma articulada um tema dado (livre ou formal); utilização da língua oral de uma forma extremamente rudimentar, limitada e na maioria dos casos pouco compreensível; detenção de uma escolaridade abaixo das suas reais potencialidades e muito inferior à dos seus pares ouvintes; obtenção de graus académicos que não correspondiam às suas reais aquisições escolares; ignorância do mundo e dos aspetos mais óbvios para qualquer criança ou jovem ouvinte em idades muito inferiores; consciência ténue do seu papel na sociedade. (AMARAL, 1996, p. 30).

O estudo tornava claro o fracasso do método oralista na educação dos surdos e era urgente repensar toda a metodologia utilizada para esta população escolar.

Em 1992 a professora Maria Augusta Amaral assumiu a direção do IJRP e no ano seguinte fez conhecer as novas linhas orientadoras para a educação de surdos no Instituto, das quais destacamos os seguintes pontos:

O processo de reabilitação da surdez é um processo sequencial e contínuo desde o diagnóstico à integração socioprofissional; o processo de reabilitação implica a intervenção de uma equipa multidisciplinar; o 
processo de reabilitação deve assentar no reconhecimento que a língua gestual é a língua materna da criança surda profunda; o desenvolvimento do processo de reabilitação da criança surda deve assentar no bilinguismo como uma estrutura fundamental; a produção e divulgação de conhecimentos resultantes de investigações, de práticas educativas e de intervenções a nível nacional são determinantes para o processo de reabilitação; a avaliação contínua é uma estratégia permanente e fundamental ao desenvolvimento deste modelo educativo. (AMARAL, 1996, p. 31).

A partir destas linhas orientadoras era necessário construir uma agenda não apenas no contexto educativo mas em vários contextos. Desde logo, o reconhecimento da LGP como primeira língua e língua natural dos surdos; a introdução desta língua não só na escola como veículo de comunicação, mas também como parte integrante dos currículos escolares; incentivar os pais, os professores e todos os intervenientes na educação de surdos a aprenderem a LGP, iniciar estudos aprofundados sobre a LGP; implementação de um modelo de educação bilíngue; incentivar o contacto com surdos adultos e associações de surdos que conduzissem à interiorização por parte dos alunos, de modelos e condutas e da cultura própria das comunidades surdas.

Estavam assim dados os primeiros passos para uma mudança total de paradigma na educação de surdos e as linhas gerais e específicas para a implementação da educação bilíngue de alunos surdos estavam traçadas mas era necessário a aplicação prática dessas linhas gerais e isso implicava mais conquistas. A maior dessas conquistas era o reconhecimento da LGP ao nível legislativo e que viria a ser uma realidade em 1997 (Lei1/97, nํ2, artigo 74으). Para este reconhecimento da LGP na Constituição da República Portuguesa concorreram duas obras de cariz científico incontornáveis, o GESTUÁRIO (Ferreira, 1992) e Para uma Gramática da Língua Gestual Portuguesa (AMARAL et. al., 1994).

\section{A Educação Bilíngue de Surdos em Portugal face à sucessiva legislação desde 1997}

A Lei Constitucional de 1997, foi um marco sem precedentes, pois, ao reconhecer a língua gestual portuguesa (LGP) como expressão cultural e 
instrumento de acesso à educação, não só correspondeu aos anseios das comunidades surdas e educativas, como abriu portas à emergência de um conjunto de medidas que foram, sucessivamente apontando para a uma orientação educativa bilingue das crianças e jovens surdos (CORREIA \& COELHO, 2019). Embora, como vimos, algumas escolas já tivessem encetado experiências educativas bilingues com alunos surdos, foi com o Despacho 7520 de 6 de maio de 1998, apoiado em recomendações e diretrizes do Parlamento Europeu (1987) das Nações Unidas (1994) e Declaração de Salamanca (1994), que as especificidades dos alunos surdos foram reconhecidas pela primeira vez na lei e que a surdez foi abordada como uma questão sociolinguística e cultural. Este despacho, além de destacar a importância da educação precoce das crianças surdas, legislou a necessidade de "assegurar, a nível do ensino, um processo que, simultaneamente, dê acesso ao domínio da língua gestual portuguesa como forma de comunicação privilegiada e ao domínio do português escrito como forma de alargamento da comunicação e como instrumento de aprendizagem".

Para tal, criou as Unidades de Apoio à Educação de Alunos Surdos (UAEAS) em estabelecimentos públicos do ensino básico e secundário, competindo a essas Unidades “a) Assegurar o desenvolvimento da língua gestual portuguesa como primeira língua; b) Assegurar as medidas pedagógicas específicas necessárias ao domínio do português, nomeadamente a nível da escrita e da leitura". Apesar disso, a formulação do Despacho 7520/98 foi considerada ambígua e deu espaço a distintas interpretações em diferentes escolas/UAEAS, tendo gerado algum descontentamento e debate por parte das comunidades surdas e educativas.

Em 2008, o Decreto-Lei 3/2008, de 7 de janeiro, veio criar as Escolas de Referência para a Educação Bilíngue de Alunos Surdos (EREBAS), as quais visaram dar corpo ao trabalho de intervenção precoce e continuada com as crianças e jovens surdos, proporcionando práticas educativas que se aproximassem mais do que se considerava serem as reais necessidades destas crianças e jovens: uma educação bilingue e bicultural (COELHO; MENDES, 2014).

Os objetivos de educação bilíngue e bicultural previstos na regulamentação das EREBAS, consistiam essencialmente, em garantir que as crianças surdas se tornassem linguisticamente competentes, providenciar o acesso a um currículo mais vasto, facilitar a literacia e fornecer aos alunos 
surdos um sentido positivo da sua própria identidade (CORREIA; COELHO, 2019). Para esse efeito, o Decreto-Lei no 3/2008 (cap. V, arto 23ㅇ, 1) (PORTUGAL, 2008) estabeleceu que: "a educação das crianças e jovens surdos deve ser feita em ambientes bilíngues que possibilitem o domínio da LGP, o domínio do português escrito e, eventualmente, falado, competindo à escola contribuir para o crescimento linguístico dos alunos surdos, para a adequação do processo de acesso ao currículo e para a inclusão escolar e social". E, para tal, determina e justifica que o fato de os alunos surdos estarem "inseridos numa comunidade linguística de referência e num grupo de socialização constituído por adultos, crianças e jovens de diversas idades que utilizam a LGP, promove condições adequadas ao desenvolvimento desta língua e possibilita o desenvolvimento do ensino e da aprendizagem em grupos ou turmas de alunos surdos, iniciando-se este processo nas primeiras idades e concluindo-se no ensino secundário. (Decreto-Lei no 3/2008, cap. V, arto 23으, 2).

As EREBAS, fazem parte de escolas ou agrupamentos de escolas regulares inclusivas, onde existem alunos surdos e ouvintes, e congregam todas as condições e recursos humanos e materiais necessários para uma educação bilíngue e bicultural, constituindo uma resposta especializada na educação das crianças e jovens surdos. Apesar de o processo de ensino/aprendizagem ser essencialmente centrado em turmas de alunos surdos, estes participam em todas as atividades desenvolvidas pela comunidade escolar. Trata-se, portanto, de um modelo de Escola Inclusiva, em tudo preparada para acolher alunos surdos e ouvintes.

Segundo Correia e Coelho (2014, p. 107) “o modelo proposto parece, assim, apontar para uma visão linguístico-cultural da surdez, ao falar de educação das crianças e jovens surdos em ambientes bilíngues, comunidade linguística de referência e grupo de socialização constituído por adultos, crianças e jovens de diversas idades que utilizam a LGP e ao apontar como objetivos das EREBAS assegurar o desenvolvimento da LGP como primeira língua dos alunos surdos. As mesmas autoras (2014) destacam ainda que a legislação evidencia o reconhecimento de um modelo linguístico-cultural da surdez em que a LGP é a língua de ensino de todas as disciplinas e também uma língua ensinada como parte integrante do currículo, sendo que as aulas de LGP têm uma carga horária igual à das aulas de LP e, de acordo com os respectivos programas, as duas línguas são estudadas nos seus aspectos 
linguísticos, metalinguísticos e culturais. As autoras suprarreferidas finalizam, assinalando que as aulas são lecionadas em LGP por docentes ouvintes com qualificação para a disciplina e competentes em LGP, ou contarão com a presença de intérprete de LGP.

Em Portugal continental e ilhas, foram criadas, inicialmente, 23 EREBAS, num processo bastante disputado e trabalhoso, uma vez que, por questões estratégicas, de distribuição de alunos e de alocação de recursos humanos e materiais, nem todas as UAEAS puderam ser reconvertidas em EREBAS. Posteriormente, esse número foi reajustado para 17, permanecendo algumas unidades a funcionar num registro semelhante aos das UAEAS. O Decreto-Lei 3/2008 vigorou e foi aplicado com sucesso, ao longo de 10 anos, nas EREBAS, tendo estas desenhado, construído e reconstruído as suas respostas educativas, sempre num quadro de Educação Bilíngue de Surdos, através do trabalho em equipes multidisciplinares, do debate e partilha de experiências e desafios, da avaliação formativa sobre o trabalho desenvolvido, bem como da formação contínua de todos os profissionais envolvidos (educadores e professores surdos e ouvintes, intérpretes de LGP, terapeutas, auxiliares de ação educativa e demais atores educativos). O projeto local desenvolvido por cada uma das EREBAS, encontrando-se sob a alçada DecretoLei $3 / 2008$, não podia distanciar-se dos pressupostos preconizados por este. Nesse sentido, encontrava-se alinhado pelas orientações e recomendações internacionais, designadamente da World Federation for the Deaf (WFD, 2007) que afirma que o conceito de integração total deve ser visto de um modo diferente para crianças surdas e ouvintes, porque as crianças surdas não podem interagir com os seus pais e professores do mesmo modo que as crianças ouvintes o fazem, e alerta também para o fato de, nas escolas regulares, as crianças surdas, estarem frequentemente expostas a situações que as excluem dos seus direitos de aprendentes surdas, do acesso visual à educação e a profissionais fluentes em língua gestual/de sinais.

Em 6 de julho de 2018, foi revogado o Decreto-Lei 3/2008 e promulgado o Decreto-Lei 54/2018, o qual, sob a égide da Educação Inclusiva, e sustentado na Declaração de Lisboa sobre Equidade Educativa (2015) propõe um modelo de inclusão no qual toda e qualquer escola deve estar apta para receber toda e qualquer criança, remetendo para as escolas a responsabilidade de criarem as condições necessárias para dar a resposta adequada a todas as crianças, sem qualquer distinção. O referido Decreto-Lei determina que: 
Mesmo nos casos em que se identificam maiores dificuldades de participação no currículo, cabe a cada escola definir o processo no qual identifica as barreiras à aprendizagem com que o aluno se confronta, apostando na diversidade de estratégias para as ultrapassar, de modo a assegurar que cada aluno tenha acesso ao currículo e às aprendizagens, levando todos e cada um ao limite das suas potencialidades (PORTUGAL, 2018).

Com efeito, as EREBAS não foram extintas, talvez porque não tenha havido coragem política para enfrentar a contestação que provocaria. Contudo, passaram timidamente para um plano secundário e, presentemente, estão a receber cada vez menos surdos sem outros problemas associados, pois estes estão sendo encaminhados para as escolas regulares da zona de residência, onde permanecem sem os recursos necessários, pois não se constrói uma escola bilíngue de um dia para o outro, nem sem falantes gestuais/sinalizadores.

Este conceito de inclusão, bem como a revogação do Decreto-Lei $3 / 2008$, causou e continua a causar um conjunto de inquietações junto da Comunidade Educativa alargada, e não apenas no âmbito da Educação de Surdos, já que ela implica um progressivo esvaziamento das escolas de referência em geral, sejam as EREBAS, sejam as Escolas de Referência no Domínio da Visão, no Domínio do Autismo, ou outro. Enquanto essa morte anunciada das escolas de referência se vai, paulatinamente, processando, os recursos humanos e materiais vão-se dispersando e dividindo, traduzidos em processos de itinerância dos profissionais, repartidos em viagens e atendimentos fugazes espalhados por diversas escolas, resultando num empobrecimento do atendimento educativo e na decadência das condições de ensino/aprendizagem das crianças que necessitam de estar incluídas, mas em escolas que, verdadeiramente lhes proporcionem as condições que as suas singularidades e especificidades requerem, para que possam ter sucesso e aprender em contextos de equidade educativa.

Recorde-se que a WFD (2007) sustenta que o ambiente menos restritivo para uma criança Surda é o mais capacitante para ela. Isto significa que a inclusão plena não é simplesmente a colocação da criança surda na escola regular onde a interação significativa com os colegas, professores e funcionários não existe. A inclusão plena significa um ambiente gestante que permita à criança desenvolver o seu potencial educativo, social e emocional. 
Por este motivo, concluímos este ponto referindo Witch, Lopes e Coelho (2019), que comentam que o Decreto-Lei 54/2018 não produz explicitamente alterações ao funcionamento das EREBAS, mas também não incide nem destaca os princípios e os fundamentos da educação bilíngue para surdos, como na legislação anterior. "Nota-se, aí, uma noção abrangente de inclusão, que proporciona uma condição esmaecida às singularidades linguísticas e culturais da experiência da surdez, isto é, às diferenças". Nesse caso, vemos um aperfeiçoamento das estratégias de governamento exercidas pelo Estado, que se tornam mais sutis e aumentam as possibilidades do seu alcance (WITCH; LOPES; COELHO, 2019, p.12).

\section{As Escolas de Referência para a Educação Bilíngue de Alunos Surdos: dois exemplos no norte de Portugal}

Nos pontos anteriores, vimos como, a partir de experiências educativas bilíngues com alunos surdos, a legislação se foi progressivamente construindo no caminho do reconhecimento e da afirmação da educação bilíngue para surdos, em Portugal. Constatamos também que a legislação atualmente em vigor, constitui um golpe e uma ameaça ao Modelo das EREBAS, muito embora, apesar de esta ter revogado o Decreto-Lei 3/2008 que as criou, não tenha logrado alcançar a sua extinção.

Neste contexto, não podemos deixar de dar conta de duas experiências educativas bilíngues desenvolvidas por duas EREBAS da zona norte de Portugal. Trata-se de duas instituições cuja experiência no âmbito da educação de surdos remonta a várias décadas atrás. Uma delas há mais de 40 anos, tendo vivenciado experiências e metodologias oralistas. Neste caso, importa destacar e partilhar a descoberta de uma professora de português e francês (hoje aposentada), que, tendo percebido que os erros dos seus alunos surdos na disciplina de língua portuguesa eram idênticos aos dos seus alunos ouvintes na língua francesa, optou por dar as aulas de português aos alunos surdos, utilizando uma metodologia de ensino de uma língua estrangeira. Esse episódio despertou nela e em outros colegas curiosidade sobre as emergentes metodologias de ensino de surdos dos países nórdicos, tendo sido dos primeiros professores a frequentar, nos anos 1980, os cursos facultados através do acordo Luso-Sueco, que deram origem aos primeiros ensaios de educação bilíngue em Portugal. 
Esta EREBAS tem, portanto uma longa experiência e tradição de educação bilíngue, que vai passando de geração em geração. Isso fez com que a Escola despertasse para a necessidade de uma intervenção precoce, junto das crianças surdas e dos seus pais, e criasse uma estrutura para esse efeito. Com as crianças surdas a partir dos três anos, foi relativamente fácil passar a fazer esse atendimento, para estimular o desenvolvimento da LGP, a socialização e a sensibilização à comunicação oral, ao nível do Jardim de Infância. No entanto, no que refere às crianças mais novas, foi necessário entabular negociações interministeriais, uma vez que, abaixo dos três anos, as crianças estão sob a tutela da Segurança Social e não do Ministério da Educação.

O mesmo se passa com a outra EREBAS, cuja experiência não é tão longa, mas que, pelo fato de abranger todos os níveis de ensino (Intervenção Precoce, Jardim de Infância, 1으, 2으 e 3ำ ciclo do ensino básico e Ensino Secundário) pode acompanhar e estimular o desenvolvimento das crianças surdas desde o momento do diagnóstico, até concluírem o 12ㅇ ano. Essa experiência tem sido extremamente gratificante, porquanto as crianças surdas precocemente imersas em programas de educação bilíngue, têm demonstrado elevadas competências sociais e acadêmicas ao atingirem o Ensino Secundário, apenas necessitando de um intérprete para as aulas, realizarem os trabalhos e os exames, com sucesso e em paridade com os seus colegas ouvintes.

Se analisarmos os princípios que sustentam a ancoragem, a criação, a existência e a longevidade das EREBAS (apesar do Decreto-Lei 54/2018), além de encontrarmos muitas afinidades com os princípios dos educadores precursores Per Aron Borg e Padre Pedro de Aguilar, encontramos também muitas similaridades com as Escolas Polo Bilíngues do município de São Paulo, no Brasil, tais como: inclusão em escolas regulares inclusivas, educação em ambientes bilíngues e biculturais, visão sociolinguística e cultural da surdez, comunidade linguística de referência, grupo de socialização, língua de sinais ou gestual como L1 e como língua de ensino e acesso ao currículo, condições pedagógicas de ensino/aprendizagem do português L2 escrito (e, eventualmente, falado), construção positiva da identidade surda, recursos humanos e materiais adequados e uma pedagogia visual.

Todos estes princípios e pressupostos atravessam, estão presentes e interpelam ambas as experiências de educação bilíngue para surdos desenvolvidas no Brasil e em Portugal, que foram abordadas neste trabalho. 
Estes entrelaçamentos espelham o conhecimento adquirido e o trabalho desenvolvido ao longo de anos, por profissionais que continuam a procurar, em cada dia, encontrar respostas adequadas às singularidades dos seus alunos surdos, não num jeito colonizador da surdez, mas numa perspectiva inclusiva, bilíngue e bicultural, na qual o discurso de inclusão não signifique a renúncia a uma identidade surda e a uma educação bilíngue e bicultural.

\section{Entrelaçamentos e considerações finais}

Le Goff (1990, p.42) nos aponta que "a história é a ciência do tempo". Nesse sentido, Brasil e Portugal, com suas experiências seculares no campo da educação de surdos, têm uma história consolidada e repleta de elementos que constituíram fundamentos para tal educação desde o século XIX. Nos séculos subsequentes, observa-se que houve avanços e outras exigências foram se estabelecendo para o campo, tendo em vista a mudança de concepções e paradigmas no que tange à educação de surdos, a implementação de políticas públicas mais focadas na comunidade surda e o impacto de perspectivas internacionais.

Ao longo deste estudo foram delineados princípios e experiências de educação bilíngue para surdos com base em marcos legais existentes no Brasil e em Portugal. Em ambos os países a língua de sinais ou gestual possui reconhecimento linguístico e a educação bilíngue é um direito educacional garantido. A existência e a opção de espaços educacionais bilíngues fazem com que os alunos surdos possam se desenvolver em, ao menos, duas línguas: língua de sinais ou gestual e língua portuguesa na modalidade escrita, além de ter uma formação acadêmica alicerçada por diversas áreas do conhecimento e considerando aspectos de sua cultura.

Ademais, as similitudes entre os países em questão se relacionam quanto à forma de organizar as escolas bilíngues, tendo em vista a presença de educadores surdos; um currículo que comporta a língua de sinais ou gestual como componente fundamental; o uso de estratégias visuais no processo de ensino, com vistas a uma aprendizagem significativa e real; a utilização de materiais didáticos voltados para tal público; a consciência de que a formação de professores é condição sine qua non para que se estabeleça um trabalho de excelência, considerando os desafios de diversas naturezas que se interpõem ao trabalho. 
Em relação às diferenças, percebemos que em Portugal, algumas EREBAS organizaram estruturas de intervenção precoce que favorecem o desenvolvimento linguístico da criança surda, a partir do acesso e aprendizado da língua gestual ou de sinais, por meio de programas específicos que englobam também a participação da família.

A incursão pelas experiências de educação bilíngue aqui tecida nos mostra que os dois países compartilham alguns ideais: a defesa pelo direito e garantia da educação pública de surdos, o fortalecimento da língua de sinais ou gestual, a aposta no ensino de língua portuguesa como segunda língua para surdos e a busca constante de qualificação dos processos pedagógicos nas escolas bilíngues. A luta continua!

\section{Referências}

ALVES, Carla Barbosa; FERREIRA, Josimário de Paula; DAMÁZIO, Mirlene Macedo. A Educação Especial na Perspectiva da Inclusão Escolar: abordagem bilíngue na escolarização de pessoas com surdez. Brasília: Ministério da Educação, Secretaria de Educação Especial; [Fortaleza]: Universidade Federal do Ceará, 2010.v. 4.

ALVES, M.C. Educação Especial e Modernização Escolar: Estudo HistóricoPedagógico da Educação de Surdos-Mudos e Cegos. 2012. Tese (Doutorado em Educação)- Instituto de Educação da Universidade de Lisboa, Lisboa, 2012.

AMARAL, M. A. O Instituto Jacob Rodrigues Pereira Contribuições para a sua História Recente, In: Para Além do Silêncio, Revista da Associação Portuguesa de Professores e Técnicos de Reabilitação de Crianças e Jovens Surdos, p. 2533.

AMARAL, M. A.; COUTINHO, A. \& DELGADO-MARTINS, R.D. Para uma gramática da Língua Gestual Portuguesa, Lisboa, Ed. Caminho, 1994.

BORG, Pedro Aron. Golpe de Vista Sobre a Necessidade, Valor e Importância de Hum Estabelecimento de Educação para os Surdos-Mudos e Cegos Em Um Estado Culto, com uma breve informação do método desta instrução, do seu 
objecto, do seu desenvolvimento, e da origem e progressos desta Instituição. Lisboa: Na Impressão da Viúva Neves e Filhos, 1823.

BRASIL. Lei no 9394 de 1996. Lei de Diretrizes e Bases da Educação Nacional. Diário Oficial da União, Brasília. Disponível em:

http://portal.mec.gov.br/arquivos/pdf/ldb.pdf. Acesso em: 7 jan. 2015.

BRASIL. Lei no. 10.436, de 24 abr. de 2002. Dispõe sobre a Língua Brasileira de Sinais-Libras e dá outras providências. Diário Oficial da União, Brasília, 25 abr. 2002.

BRASIL. Decreto no. 5.626, de 22 dez. 2005. Regulamenta a Lei no 10.436, de 24 de abril de 2002, que dispõe sobre a Língua Brasileira de Sinais - Libras, e o art. 18 da Lei no 10.098, de 19 de dezembro de 2000. Diário Oficial da União, Brasília, 23 dez. 2005.

BRASIL. Atendimento Educacional Especializado Pessoa com Surdez.

Disponível em: http://portal.mec.gov.br/seesp/arquivos/pdf/aee_da.pdf. Acesso em: 7 jan. 2015.

BRASIL. Política Nacional de Educação Especial na Perspectiva da Educação Inclusiva. Brasília: MEC/SEESP, 2008. Disponível em:

http://portal.mec.gov.br/seesp/arquivos/pdf/politica.pdf. Acesso em: 26 jul. 2020.

BRASIL. Lei no 13.146, de 6 de julho de 2015. Institui a Lei Brasileira de Inclusão da Pessoa com Deficiência (Estatuto da Pessoa com Deficiência). Disponível em:

<http://www.planalto.gov.br/ccivil_03/_ato2015-2018/2015/lei//13146.htm>. Acesso em: 27 jul. 2020.

CARVALHO, Paulo Vaz. O Abade de L’Epée no Século XXI. Disponível em: http://www.porsinal.pt/index.php?ps=artigos\&idt=artc\&cat=7\&idart=307. Acesso em: 1 jan. 2015. 
COELHO, Orquídea; MENDES, Bruno. Crianças Surdas Implantadas, Trabalho Pedagógico e Envolvimento Parental numa Perspectiva de Educação Bilingue. In: ANDREIS-WITKOSKI, Silvia; FILIETAZ, Marta Rejane (Ed.), Educação de Surdos em Debate (p. 129-145). Curitiba, Paraná (BR): UTFPR - Universidade Tecnológica Federal do Paraná. Disponível em: http://repositorio.utfpr.edu.br/jspui/handle/1/3548. Acesso em: 3 ago. 2020.

CORREIA, Fátima Sá; COELHO, Orquídea. Revolução de Abril, educação de surdos/as e ensino da filosofia: Da deficiência à pertença cultural. Educação, Sociedade \& Culturas, v. 43, p. 103-119, 2014. Disponível em: http://www.fpce.up.pt/ciie/sites/default/files/ESC43_Correia\%26Coelho.pdf. Acesso em: 4 ago. 2020.

CORREIA, Fátima Sá; COELHO, Orquídea. O modelo bilingue da educação de surdos em Portugal. In: Isabel Correia, Pedro Custódio, \& Ronaldo Campos (Orgs.). Línguas de Sinais: Cultura, Educação, Identidade, p. 41-58. Lisboa: Edições Ex-Libris, 2019.

COSTA, Antônio da. No Minho. Lisboa: Imprensa Nacional, Lisboa, 1874.

DETIENNE, Marcel. Construir Comparáveis, In: DETIENNE, Marcel. Comparar o incomparável. São Paulo: Ideias e Letras, 2004.

DONATO, Adriana Di; DINIZ, Sandra. Libras I. UFPB, 2017. Disponível em: http://biblioteca.virtual.ufpb.br/files/libras_i_1330350583.pdf. Acesso em: 31 jul. 2020.

FERREIRA, A. V. (Ed.). Gestuário da Língua Gestual Portuguesa. Lisboa: Secretariado Nacional para a Reabilitação e Integração de Pessoas com Deficiência, 1992.

FUSILLIER, Anicet . "Esboço histórico do ensino dos surdos-mudos em Portugal. Estudo apresentado ao Congresso pedagógico hispano-português-americano realizado em Madrid em outubro de 1892. Pe. Pedro Maria de Aguilar". Instrução e Educação dos Surdos-Mudos (21-30). Lisboa: Empresa de Lucas Evangelista Torres. Biblioteca Nacional de Portugal, 1893. 
GREGORY, Susan. Bilingualism and the Education of Deaf Children. Disponível em: http://www.leeds.ac.uk/educol/documents/000000306.htm. Acesso em: 4 ago. 2020.

GIL, Antônio Carlos. Como elaborar projetos de pesquisa. São Paulo: Editora Atlas, 2002.

LE GOFF, Jacques. História e memória / Jacques Le Goff; tradução Bernardo Leitão... [et al.]. Campinas, SP: Editora da UNICAMP, 1990.

L'ÉPÉE, Charles Michel de. Institution des Sourds-muets par la voie des Signes Méthodiques, Part.1, Cap.IV, 1776.

PERLIN, Gladis T.T. Identidades Surdas. In: Atualidades da educação bilíngue para surdos: processos e projetos pedagógicos. Porto Alegre: Mediação, 1998.

PORTUGAL. Decreto-Lei $\mathbf{n} .3$ de 2008: Define os apoios especializados a prestar na educação pré-escolar e nos ensinos básico e secundário dos sectores público, particular e cooperativo. Disponível em:

https://dre.pt/pesquisa/-/search/386871/details/normal?q=Decreto-Lei+n. \%C2\%BA\%203\%2F2008\%2C\%20de+7+de+janeiro. Acesso em: 24 jul. 2020.

SACKS, Oliver. Vendo vozes: uma jornada pelo mundo dos surdos. Rio de Janeiro: Imago, 1990.

SANTOS, Angélica Niero Mendes dos. A língua brasileira de sinais na educação de surdos: língua de instrução e disciplina curricular. 2018. 265 p. Dissertação (Mestrado - Programa de Pós-Graduação em Educação), Área de Concentração: Educação e Ciências Sociais: desigualdades e diferenças)Faculdade de Educação da Universidade de São Paulo, 2018.

SÃO PAULO (SP). Secretaria Municipal de Educação. Diretoria de Orientação Técnica. Orientações curriculares e proposição de expectativas de aprendizagem para Educação Infantil e Ensino Fundamental: Libras / Secretaria Municipal de Educação. São Paulo: SME / DOT, 2008. 
SÃO PAULO (SP). Secretaria Municipal de Educação. Diretoria de Orientação Técnica. Orientações curriculares e proposição de expectativas de aprendizagem para Educação Infantil e Ensino Fundamental: Língua Portuguesa para pessoa surda / Secretaria Municipal de Educação. São Paulo: SME / DOT, 2008.

SÃO PAULO (SP). Secretaria Municipal de Educação. Decreto no 52.785 de 10 de novembro de 2011. São Paulo, 2011.

SÃO PAULO (SP) Comunicado no 567, de 30 de março de 2012. Disponível em: http://www.radaroficial.com.br/d/767568. Acesso em: 27 jul. 2020.

SÃO PAULO (SP). Secretaria Municipal de Educação. Decreto no 57.379 de 2016: Institui no Sistema Municipal de Ensino a Política Paulistana de Educação Especial, na Perspectiva da Educação Inclusiva. Disponível em: http://legislacao.prefeitura.sp.gov.br/leis/decreto-57379-de-13-de-outubrode-2016. Acesso em: 27 jul. 2020.

SÃO PAULO (SP). Portaria no 6571, de 25 de novembro de 2014. Institui as Matrizes Curriculares para as Escolas Municipais de Ensino Fundamental EMEFs, Escolas Municipais de Ensino Fundamental e Médio - EMEFMs, Escolas Municipais de Educação Bilíngue para Surdos - EMEBSs e dá outras providências. Portaria 6571/14 - SME. São Paulo, Disponível em: https://www.sinesp.org.br/quem-somos/legis/375-organizacao-escolar/ organizacao-da-unidade-educacional/3922-portaria-n-6-571-de-25-11-2014institui-as-matrizes-curriculares-para-as-escolas-municipais-de-ensinofundamental-emefs-escolas-municipais-de-ensino-fundamental-e-medioemefms-escolas-municipais-de-educacao-bilingue-para-surdos-emebss-e-daoutras-providencias. Acesso em: 26 jul. 2020.

SÃO PAULO. Portaria no 5.707, de 12 de dezembro de 2011. Regulamenta o decreto 52.785 de 10/10/11 que criou as escolas de educação bilíngue para surdos - emebs na rede municipal de ensino e dá outras providências.

Disponível em: 
http://portalsme.prefeitura.sp.gov.br/Projetos/supervisao/Anonimo/DOC \%202011/P5707EMEBS.htm. Acesso em: 8 jan. 2015.

SÃO PAULO (SP). Secretaria Municipal de Educação. Coordenadoria Pedagógica. Currículo da cidade: Educação Especial: Língua Portuguesa para surdos. - São Paulo: SME / COPED, 2019.

SÃO PAULO (SP). Secretaria Municipal de Educação. Coordenadoria Pedagógica. Currículo da cidade: Educação Especial: Língua Brasileira de Sinais. - São Paulo: SME / COPED, 2019.

SÃO PAULO (SP). Secretaria Municipal de Educação. Diretoria de Orientação Técnica. Cadernos de apoio e aprendizagem: Libras - 10 ano / Secretaria Municipal de Educação - São Paulo: SME / DOT, 2012.

SKLIAR, Carlos (org.). A surdez: um olhar sobre as diferenças. Porto Alegre: Mediação, 1998.

SKLIAR, Carlos. Bilingüismo e biculturalismo: uma análise sobre as narrativas tradicionais na educação dos surdos. Revista Brasileira de Educação, n. 8, maio/jun./jul./ago., 1998.

SKLIAR, Carlos. Atualidades da educação bilíngue para surdos: processos e projetos pedagógicos. Porto Alegre: Mediação, 1999.

WITCHS, Pedro Henrique; LOPES, Maura Corcini; COELHO, Orquídea. Formas possíveis de ser nas políticas linguísticas de educação de surdos em Portugal. Revista Educação e Sociedade, v.40, Campinas, julho, 2019.

O presente trabalho foi realizado com o Apoio da Coordenação de Aperfeiçoamento de Pessoal de Nível Superior- Brasil (CAPES)- Código de Financiamento 001" / This study was financed in part by the Coordenação de Aperfeiçoamento de Pessoal de Nível Superior- Brasil (CAPES)- Código de Finance Code 001. 